\title{
Benign sclerosing pneumocytoma of lung (sclerosing haemangioma)
}

\author{
KEENG-WAI CHAN, ${ }^{*}$ ALLEN R GIBBS, $\uparrow$ WS LO, GR NEWMAN** \\ From the *Kowloon Institute of Pathology, Kowloon Hospital, Hong Kong; †Department of Pathology, \\ Welsh National School of Medicine, Cardiff; $\ddagger$ Kowloon Hospital, Hong Kong; and ${ }^{* *}$ Department of \\ Pathology, University Hospital of Wales, Cardiff
}

ABSTRACT The clinical and histopathological features of 14 cases of so-called sclerosing haemangioma of the lung are described. All developed in Hong Kong Chinese women. Histochemical and ultrastructural study of these tumours indicates an epithelial origin. The term benign sclerosing pneumocytoma is suggested as being more appropriate for this unusual tumour.

Liebow and Hubbell in 1956 described seven examples of a rare, benign pulmonary tumour under the term sclerosing haemangioma. ${ }^{1}$ Patients presented with haemoptysis or with a coin lesion. The tumour showed a striking preponderance in women and was characterised microscopically by "vascular channels," sclerosis, papillae, sheets of cells, and haemorrhage in varying proportions. Considerable diagnostic confusion has occurred, however, since some of the reports have included plasma cell granuloma and histiocytic lesions inappropriately under the term sclerosing haemangioma and the reverse has also occurred. ${ }^{2-9}$ We review the clinicopathological features of 14 "sclerosing haemangiomas" that comply fully with the criteria of Liebow and Hubbell. This is the second largest series to be reported. ${ }^{1-18} \mathrm{We}$ also report the electronmicroscopic and histochemical findings for several of these tumours. On the basis of these findings we proffer the term benign sclerosing pneumocytoma as being more appropriate for this unusual tumour.

\section{Methods}

The 14 cases of "sclerosing haemangioma" studied were taken from the file of the Institute of Pathology, Hong Kong, from 1974 to 1980 . Ten of these cases came from the Cardiothoracic Unit, Kowloon Hospital, including four that presented in 1980. The five most recent cases were also examined by electron microscopy from formalin-fixed material.

All specimens were fixed in $10 \%$ buffered forma-

Address for reprint requests: Dr AR Gibbs, Department of Pathology, Welsh National School of Medicine, Cardiff CF4 4XN. lin. One to six blocks were taken from each tumour for paraffin embedding. Sections were cut and stained with haematoxylin and eosin, Victoria blue, Van Gieson's, Gordon and Sweet's reticulin method, Alcian blue/Unna Pappenheim technique (AB/UP), Periodic Acid-Schiff method with (PAS-D) and without (PAS) diastase digestion, and Perl's method. Frozen sections were cut and stained with oil red $\mathrm{O}$.

Case 13 was submitted fresh and frozen sections were cut for enzyme studies-acid phosphatase by Barka's modified technique, ${ }^{19}$ non-specific esterase by the method of Davis and Ornstein, ${ }^{19}$ and alkaline phosphatase by Gomori's method. ${ }^{20}$

Tissue, fixed for periods over two weeks in buffered formalin, was refixed in $2.8 \%$ glutaraldehyde in a $0.1 \mathrm{~mol}$ phosphate buffer at $\mathrm{pH} 7 \cdot 4$. After osmication in $2 \%$ veronal acetate buffered osmium tetroxide the tissue was treated en bloc with $3 \%$ aqueous uranyl acetate dehydrated and embedded in Epon 812. Thin sections were stained on the grid in lead citrate.

\section{Results}

CLINICAL FEATURES (table 1)

All cases occurred in females; the age ranged from 16 to 78 years (average $50 \cdot 8$, median 55 years). Seven were symptom free and the lesion was discovered by routine chest radiography; cough was present in five patients; four had haemoptysis; one had ill-defined chest pain. The size of the tumour varied from $13 \mathrm{~mm}$ to $35 \mathrm{~mm}$ in diameter (average $23.3 \mathrm{~mm}$ ). Most of the tumours were located beneath the pleura, sometimes bulging out as a sessile polypoid growth. In some cases the lesions were 
Table 1 Clinical summary of 14 cases (all in women) of "sclerosing haemangiomas" of lung

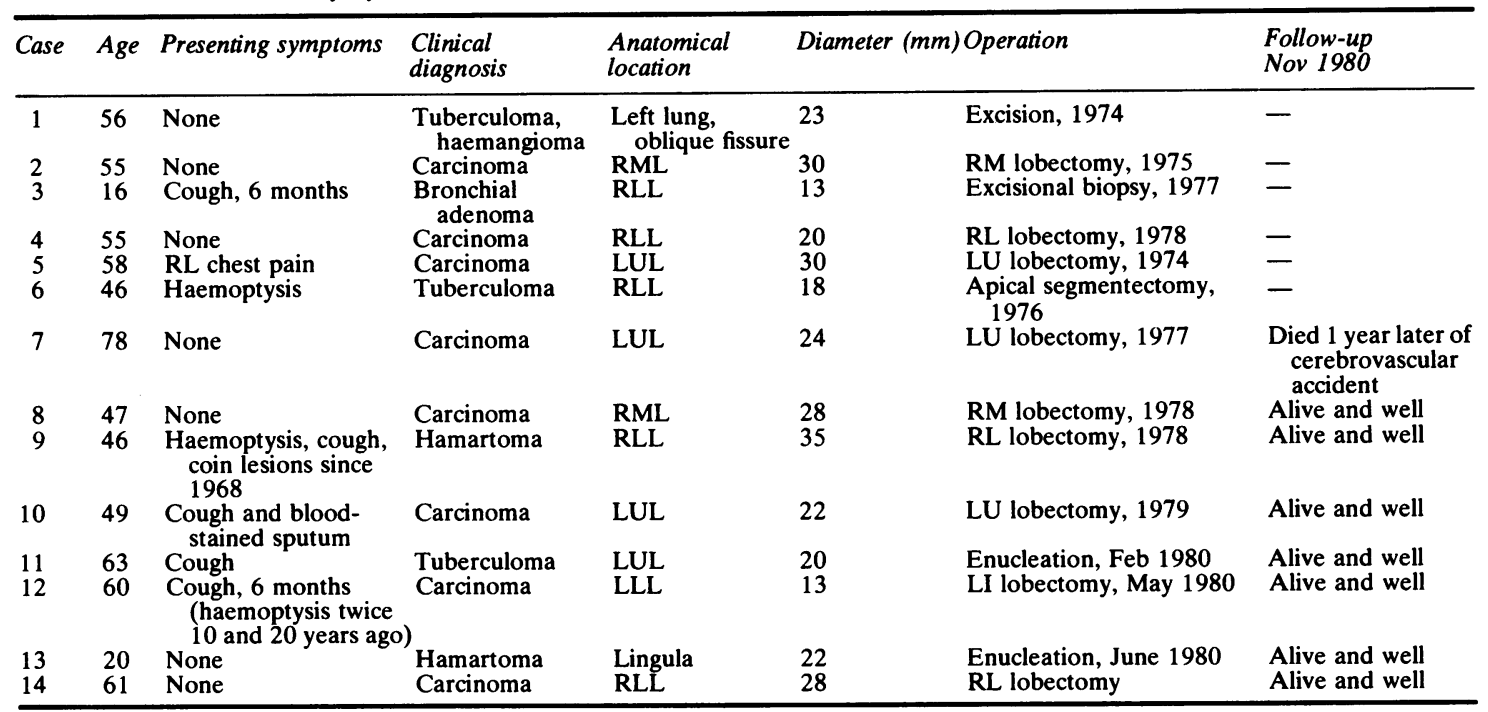

LUL = left upper lobe $\mathrm{RML}=$ right middle lobe

LLL $=$ left lower lobe $\quad$ RLL $=$ right lower lobe.

situated near a segmental bronchus (fig 1). In case 1 it was situated over the oblique fissure of the left lung.

Seven of the 10 patients operated on at Kowloon Hospital were interviewed during November 1980 by one of us (WSL) and found to be well. One patient had died of cerebral haemorrhage a year after operation. No follow-up information was available for the two remaining cases or the four cases not operated on at Kowloon Hospital. No patient was known to have shown recurrence or dissemination of the tumour.

\section{PATHOLOGY}

\section{Gross appearance}

The tumours were well circumscribed, soft to firm, and surrounded by a pseudocapsule. The cut surface usually had a variegated appearance, yellowish to grey with scattered reddish-brown areas. Sometimes necrosis and calcification were present. Occasional tumours were more uniform in appearance and minute cleft-like spaces were sometimes seen (fig 1).

\section{Light-microscope appearance}

Four major histological patterns-solid, papillary, angiomatoid, and sclerotic-were encountered in varying proportions within these tumours (table 2). Solid, papillary, and sclerotic areas (figs 2 and 3 ) were evident in every tumour, although they sometimes had to be searched for. Angiomatoid areas

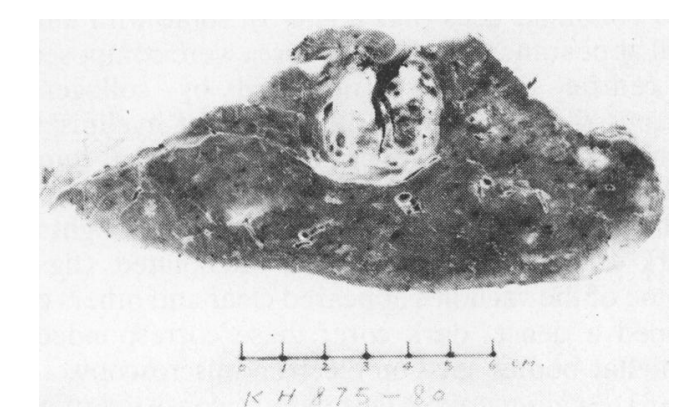

Fig 1 Case 14: centrally located tumour close to a segmental bronchus.

(figs 2 and 4), however, were absent in four of the tumours.

(1) Solid-These areas consisted of sheets and irregular masses of plump fusiform or polygonal cells with moderate amounts of eosinophilic cytoplasm and round, ovoid, or slightly convoluted nuclei with a fine chromatin pattern and small discrete nucleolus. Occasional nuclei were grooved. Mitoses were rare. Sometimes large cells with clear cytoplasm were present. Silver impregnation showed reticulin surrounding groups of cells. 
Table 2 Summary of histological features of 14 "sclerosing haemangiomas"

\begin{tabular}{|c|c|c|c|c|c|c|c|c|c|c|c|}
\hline Case & Solid & Papillary & Angiomatoid & Sclerosis & $\begin{array}{l}\text { Clear } \\
\text { cells }\end{array}$ & Haemorrhage & Haemosiderin & $\begin{array}{l}\text { Foam } \\
\text { cells }\end{array}$ & $\begin{array}{l}\text { Mast } \\
\text { cells }\end{array}$ & Fat & Glycogen \\
\hline 1 & ++ & + & ++ & ++ & 0 & $\begin{array}{l}++ \\
\text { (Calcification) }\end{array}$ & + & + & + & + & + \\
\hline 2 & + & + & ++ & ++ & 0 & ++ & $\begin{array}{l}++ \\
\text { Siderotic nodule }\end{array}$ & \pm & ++ & + & + \\
\hline 3 & + & + & + & + & 0 & ++ & $\begin{array}{l}++ \\
\text { (Haematoidin }+)\end{array}$ & \pm & ++ & + & \pm \\
\hline 4 & + & ++ & 0 & + & + & + & + & + & + & + & \pm \\
\hline 5 & + & + & ++ & + & 0 & ++ & + & + & + & ++ & \pm \\
\hline 6 & + & + & 0 & + & 0 & + & + & + & + & ++ & \pm \\
\hline 7 & ++ & + & + & + & + & $\begin{array}{l}++ \\
\text { (Calcification) }\end{array}$ & $\begin{array}{l}++ \\
\text { Siderotic nodule }\end{array}$ & \pm & ++ & + & + \\
\hline 8 & $+t$ & + & + & + & 0 & + & + & + & ++ & + & + \\
\hline 9 & ++ & + & + & + & 0 & + & ++ & + & + & + & + \\
\hline 10 & ++ & + & + & + & 0 & ++ & $\begin{array}{l}++ \\
(\text { Haematoidin }+)\end{array}$ & + & ++ & + & + \\
\hline 11 & \pm & ++ & 0 & \pm & 0 & $\begin{array}{l}+ \\
\text { (Necrosis) }\end{array}$ & ++ & ++ & + & + & + \\
\hline 12 & ++ & + & ++ & + & 0 & ++ & $\begin{array}{l}++ \\
\text { (Haematoidin }+ \text { ) } \\
\text { Siderotic nodule }\end{array}$ & \pm & ++ & + & + \\
\hline 13 & + & ++ & 0 & + & + & + & + & + & \pm & + & \pm \\
\hline 14 & ++ & \pm & ++ & ++ & 0 & $\begin{array}{l}++ \\
\text { (Calcification) }\end{array}$ & $\begin{array}{l}++ \\
\text { Siderotic nodule }\end{array}$ & \pm & ++ & + & \pm \\
\hline
\end{tabular}

$0=$ absent $+=$ present $\pm=$ scanty $++=$ predominant or abundant.

(2) Papillary-This pattern consisted of irregular anastomosing, cleft-like spaces with projections of papillary structures covered by a layer of cuboidal to low columnar cells (figs 2 and 3 ), some with a hobnail appearance (fig 6). The cores were composed of a central capillary surrounded by collagenous fibrous tissue with varying degrees of hyalinisation admixed with variable numbers of rounded tumour cells (figs 2 and 3 ). Semi-thin sections showed the cells lining the papillae to be a mixture of light and dark cells. Several appeared vacuolated (fig 7). Some of the vacuoles appeared clear and others contained a dense, dark core; these corresponded to lamellar bodies seen on electron miscroscopy.

(3) Angiomatoid - This pattern consisted of clusters of variable-sized honeycomb spaces containing red blood cells (figs 2 and 4), some without apparent lining cells, others lined by flattened or cuboidal cells. Elastic staining showed a complete absence of elastic tissue.

(4) Sclerotic-These areas were irregular in size and shape and composed of dense fibrous tissue with varying amounts of hyalinisation. Elastic tissue was sparse (fig 3).

Associated features-(1) Haemorrhage: this was irregular in distribution, with extravasation of red blood cells adjacent to the angiomatoid areas, within solid areas and within the lung parenchyma surrounding the tumour. (2) Haemosiderin: in some cases siderotic nodules and haematoidin pigments were also seen. (3) Foamy histiocyte-like cells, mast cells, and other chronic inflammatory cells varied from sparse to conspicous in different tumours. (4) Fat droplets were evident in cells lining channels and forming solid areas; oil-red-O-positive material was also present in sclerotic areas. (5) Necrosis, cholesterol clefts, and calcification were occasionally present.

\section{Histochemical findings}

Enzyme studies performed on fresh tissue from one of the tumours showed slight-to-moderate nonspecific esterase activity and slight acid phosphatase activity but no alkaline phosphatase activity in the tumour cells.

\section{Electron-microscope findings}

All five tumours showed similar ultrastructural features so they will be described together. The predominant cellular component, regardless of whether it formed sheets, lined papillae or vascular spaces, or was enmeshed in collagen, was considered to be epithelial and to show three forms. There were "dark" cells, "light" cells, and cells transitional between light and dark (fig 8), the variation depending on the quantity of cytoplasmic organelles. Dark cells manifested fairly large amounts of rough endoplasmic reticulum, glycogen, and free ribosomes. These were relatively scanty in light cells and intermediate in amount in transitional cells. Otherwise the three categories of cells showed similar characteristics. They were rectangular, cuboidal, or polygonal with an irregular indented nucleus and peripheral, irregularly condensed chromatin. Most 


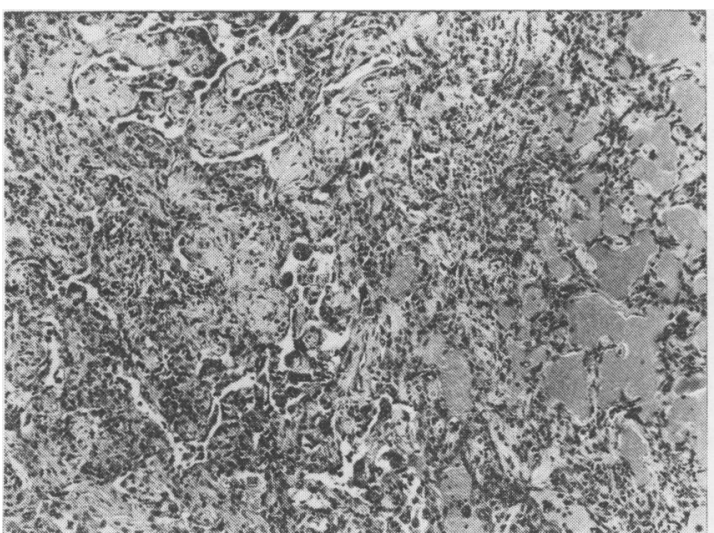

Fig 2 Case 1: this shows papillary (left and top), solid (centre right), and angiomatoid (right) areas ( $H$ and $E \times$ $60)$.

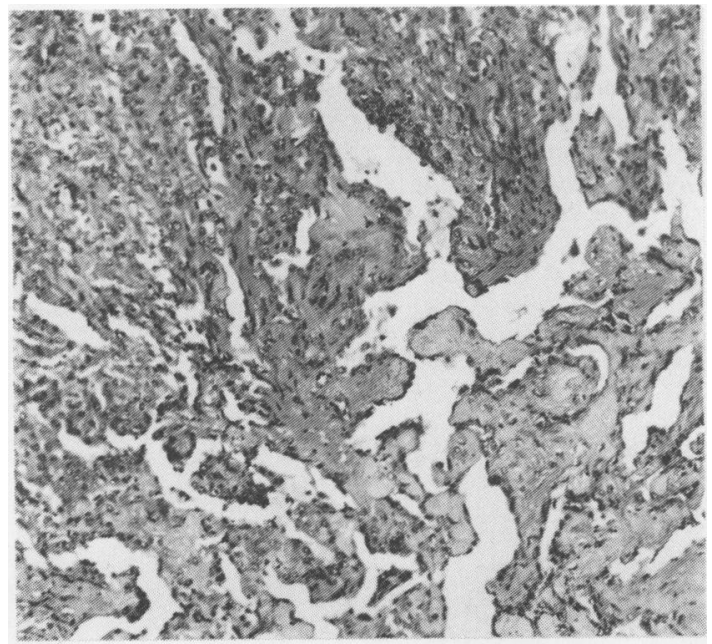

Fig 3 Case 1: this shows solid area and characteristic papillae formation with sclerotic areas ( $H$ and $E \times 33$ ).

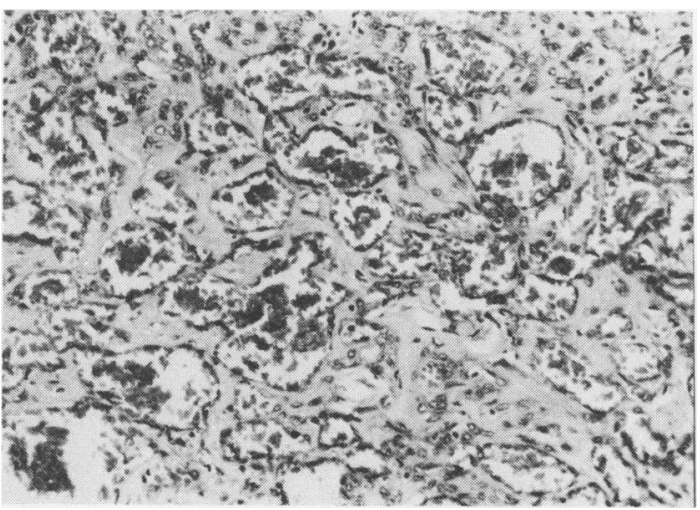

Fig 4 Case 12: angiomatoid areas; irregular spaces, some lined by flattened cells, containing red blood cells ( $H$ and $E$ $\times 110)$.

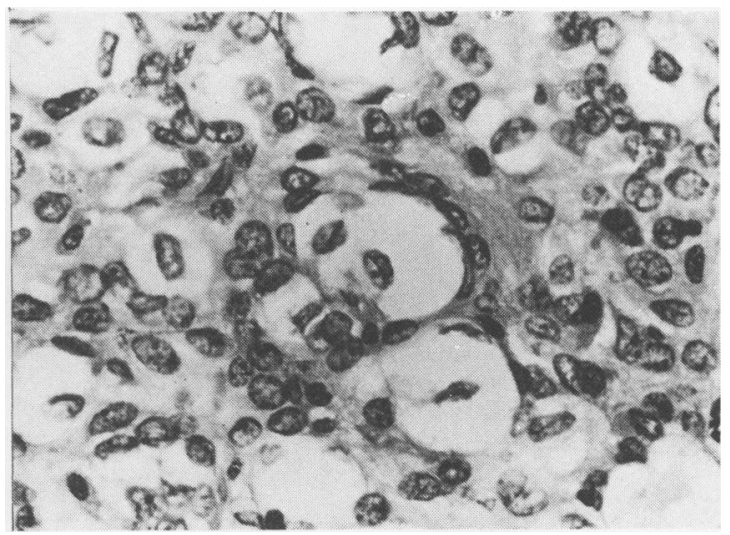

Fig 5 Case 7: clear cells with grooved nuclei ( $H$ and $E \times$ 445).

of these cells contained a single prominent central or eccentric nucleolus but occasionally two nucleoli were observed (fig 9). The Golgi apparatus was usually rudimentary. Moderate numbers of well-formed elongated mitochondria were present. Variable numbers of desmosome-like attachments and tight junctions were observed between the cells. The cells possessed numerous microvillous processes, which in many areas formed complex interdigitating folds (fig 9) but no cilia. Several of the cells contained electron-dense bodies. These varied from one or two per cell within a given section to considerable numbers packing out the cytoplasm. They also varied considerably in size, shape, and complexity. They ranged from small, rounded bodies with a dense central area and light peripheral rim or small rounded bodies with a light centre and dense rim to large complex lamellar structures (fig 10). Multivesicular bodies that appeared to be developing within the lamellar structures were also observed. All these were considered to represent stages in development of lamellar bodies as seen in normal type 2 pneumocytes. Many of the cells which appeared foamy on light microscopy, and thus macrophage-like in appearance, were found to be vacuolated epithelial cells. While many of the vacuoles appeared to be empty, some showed residual lamellar structures (fig 11). This appearance was seen in cells lying free within spaces and also within cells lining channels. Basement membrane material was present at the base of cells which lined channels and papillae, between some of the cells forming solid sheets, and within the stroma of the sclerotic areas. Occasional cells lining haemorrhagic spaces or papillae contained numerous mucous vacuoles and were interpreted as mucous cells (fig 10). 


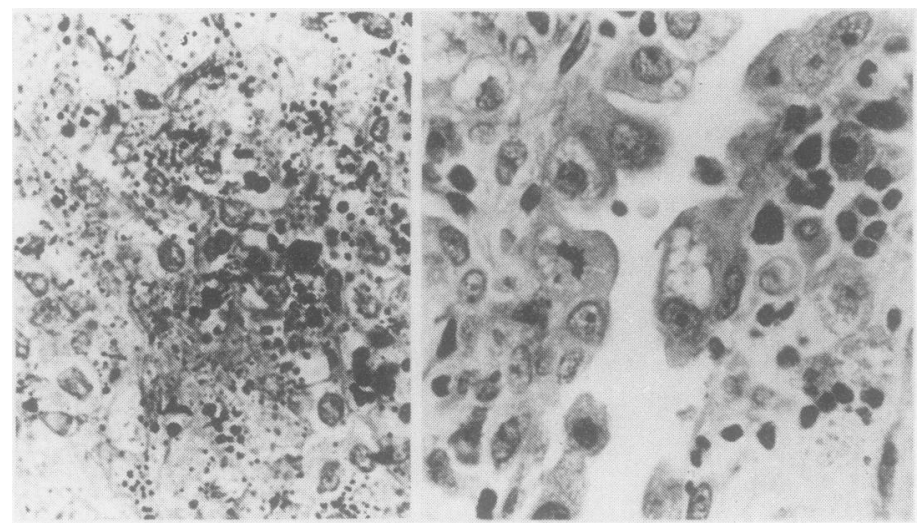

Fig 6 (left) Case 8: abundant glycogen granules in the solid areas $(P A S \times 470)$.

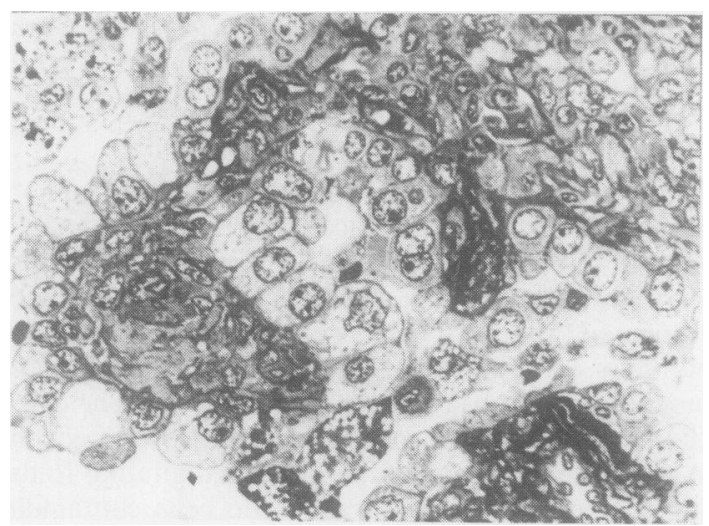

Fig 6 (right) Case 11: hobnail cells covering the papillary projections with cleft-like spaces in between; note a mitotic figure and cells with prominent nucleoli ( $H$ and $E \times 470$ ).

Fig 7 A semi-thin section of a papillary area showing vacuolation of several of the cells lining the papillae; some of the vacuoles are clear areas, others contain a dense homogenous core (toluidine blue $\times 310$ ).

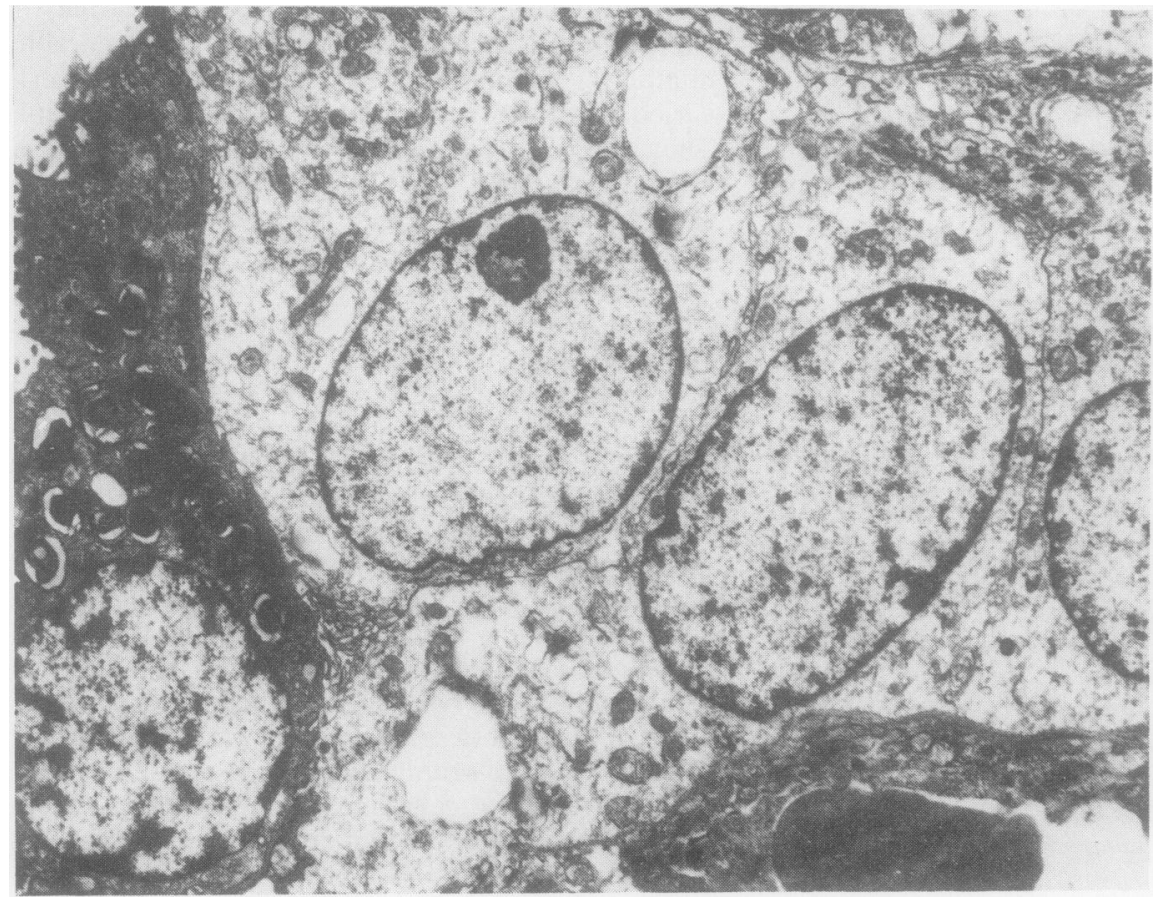

Fig 8 The edge of $a$ solid area showing light and dark cells with microvillous and interdigitating borders and tight junctions; the dark cells show many complex lamellar structures and smaller simpler dense bodies; a capillary is present at the bottom right $(\times 4610)$. 


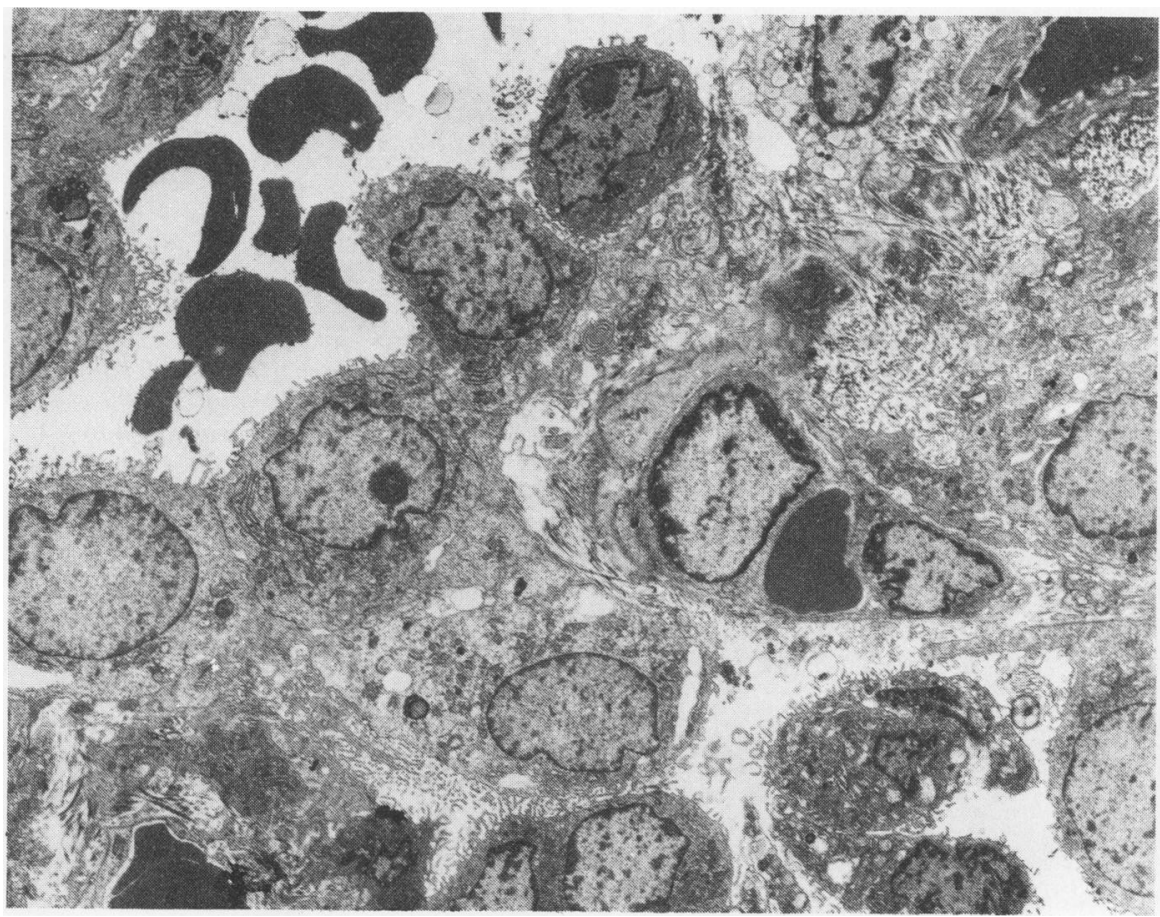

Fig 9 An "angiomatoid" area showing rectangular and cuboidal cells lining a blood-containing channel. The cells show many microvilli, have irregular indented nuclei, and contain occasional dense bodies. At the bottom right there is a "desquamated" cell that appears similar to the lining cells; and at the top of the picture a cell containing mucous vacuoles can also be seen lining the channel $(\times 2140)$.

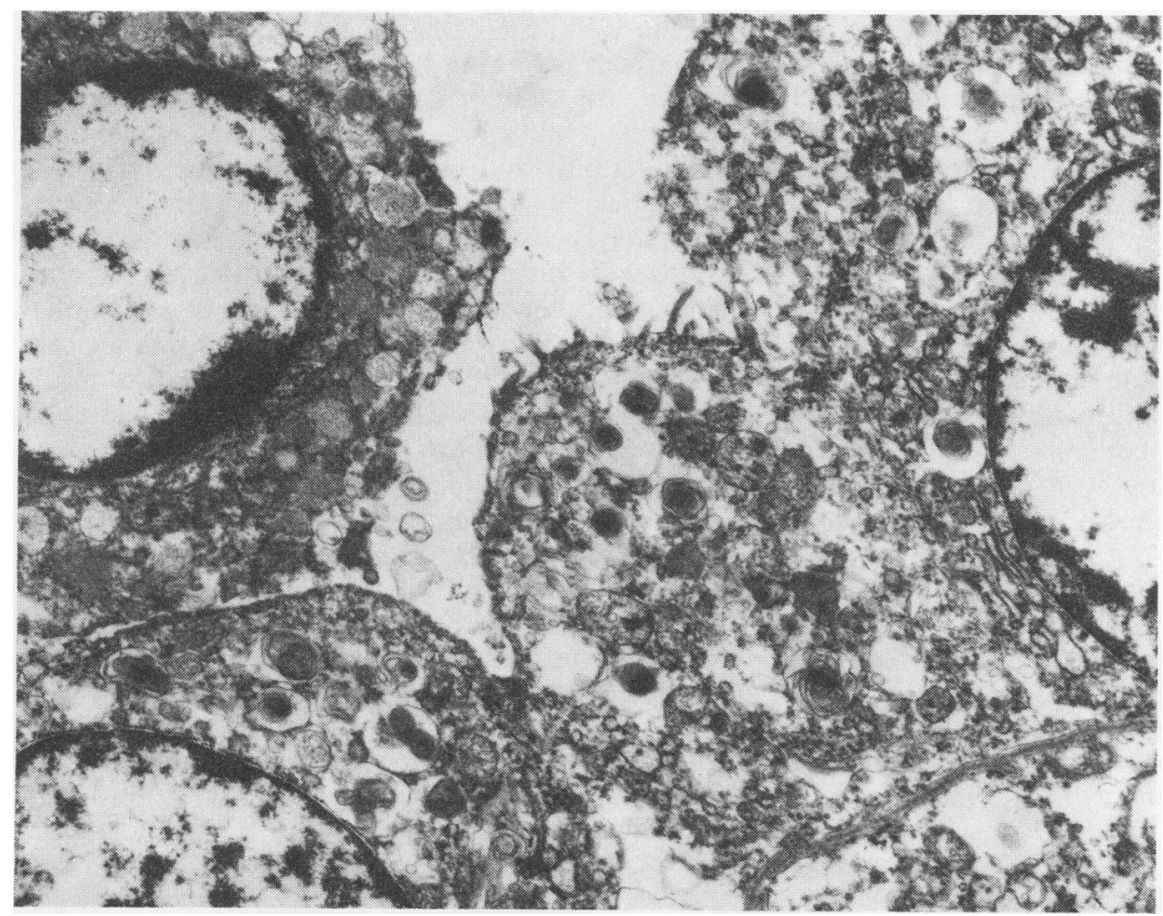

Fig 10 In this area the - lining cells contain numerous complex lamellar bodies; on the left a mucous cell is evident $(\times 8050)$. 


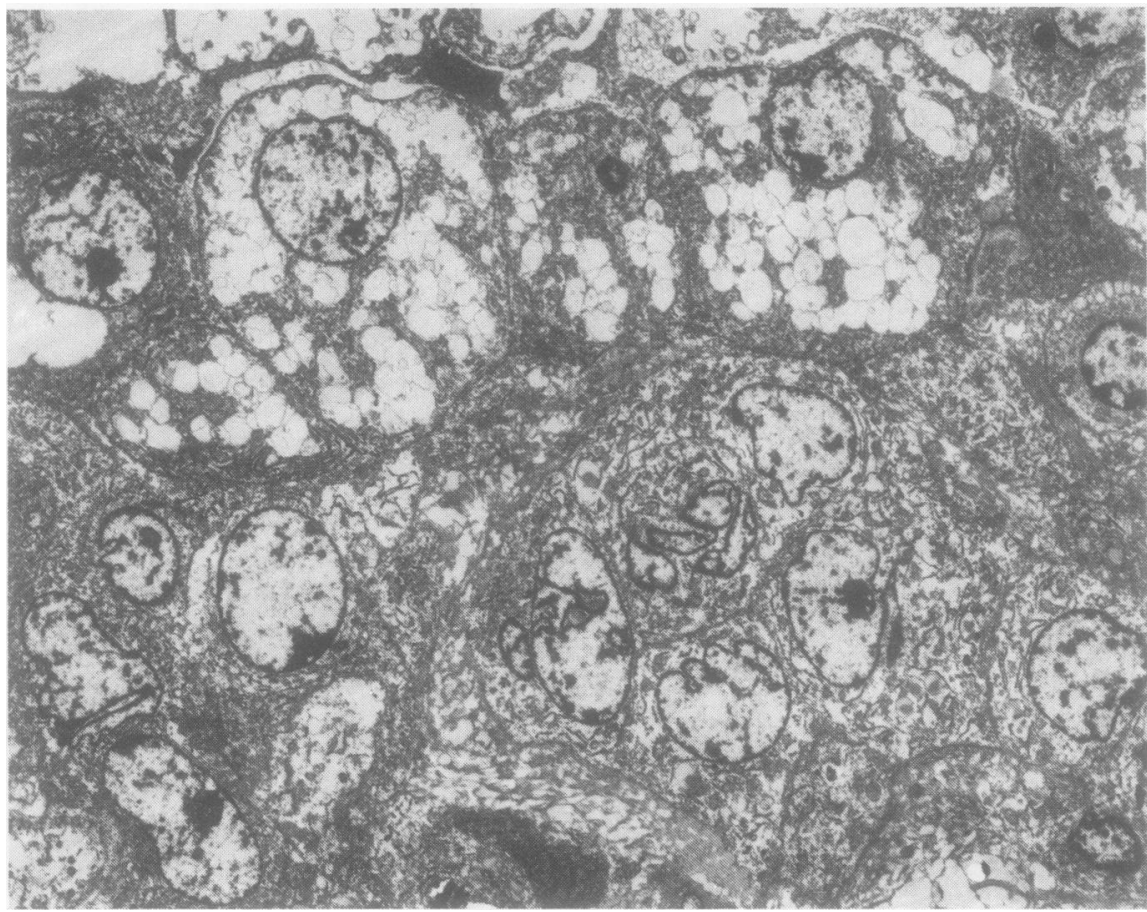

Fig 11 A solid area in which some of the cells show many membranebound spaces and some show lamellar dense bodies $(\times 1775)$.

Within spaces the majority of the cells were red blood cells or epithelial cells (fig 9), many of the latter containing complex lamellar electron-dense bodies. There were occasional macrophages containing similar lamellar structures, presumably phagocytosed, and many fragments of lamellar osmiophilic material (figs 9 and 10). The sclerosed areas contained large amounts of collagen, elastic, basement membrane material, fibroblasts, portions of epithelial cells, and osmiophilic (sometimes lamellated) debris within the stroma.

Occasional mast cells, plasma cells and lymphocytes were seen within the tumour. Occasional capillaries were identified in the tumour but they showed a normal morphology and were not considered to represent a neoplastic component of the tumour. "Weibel-Palade" bodies were not identified in tumour cells despite intensive search.

\section{Discussion}

All 14 tumours occurred in women, which is in agreement with the striking female preponderance in previously reported series. ${ }^{1-18}$ The age range was wide (16-78 years), which compares with the series reported by Katzenstein et $a^{10}$ (15-69 years). No particular predilection for any lobe was noted but most were located near the pleura. All were solitary; but multiple tumours have been reported. ${ }^{10}$
Histologically, the tumour shows a variety of features, which are distinctive but generally not well recognised. Whereas Kennedy ${ }^{14}$ emphasised the papillary pattern of the tumour this was not the most prominent feature in most of our cases. If sufficient blocks are examined, a spectrum of histological features will be observed-solid, papillary, angiomatoid, and sclerotic patterns and variable quantities of haemorrhage, haemosiderin, foamy cells, mast cells, lymphoid cells, fat, and glycogen. It is this wide range of patterns that has caused confusion with other tumours. Katzenstein et al ${ }^{10}$ emphasised the presence of distinctive round tumour cells and stated that they were a constant feature in the stroma of all microscopic patterns. They were also consistently present in our cases.

Enzyme studies performed on fresh tissue from one of our tumours showed slight-to-moderate non-specific esterase activity, slight acid phosphatase activity, and no alkaline phosphatase activity, which, together with the presence of glycogen, suggest that the tumour cells are epithelial rather than endothelial in type since (1) pneumocytes may contain acid phosphatase and non-specific esterase, whereas endothelium does not ${ }^{21} 22$; (2) pneumocytes may contain glycogen granules, ${ }^{22-24}$ whereas endothelial cells usually lack it $^{22}$; (3) endothelial cells and pneumocytes may contain alkaline phosphatase. ${ }^{22} 25$ Only one other histochemical study of 
sclerosing haemangioma has been reported..$^{18}$ Here the tumour cells were negative with ATP-ase and focally positive for alkaline phosphatase in some of the cells lining the tumour spaces.

The results of electron-microscope examination of nine cases of sclerosing haemangioma have been reported; some favoured an epithelial origin, ${ }^{13-18}$ whereas others ${ }^{1112}$ concluded that it was endothelial. There are three possible reasons for these contradicting conclusions. (1) Not all the tumours studied complied with the original light-microscope description of sclerosing haemangioma. Our perusal of the illustrations shown by each of the above authors makes this explanation very unlikely. (2) Electron-microscope examination of tumours has inherent sampling problems and possibly the areas examined in some cases were not truly representative of the tumour. (3) There may have been interpretative differences. This is a variegated tumour and one element may be interpreted as "entrapped" by one author or "neoplastic" by another.

We are quite certain that the five cases we examined ultrastructurally conform to the original description of Liebow and Hubbell ${ }^{1}$ in every way. From our own study we firmly conclude that sclerosing haemangioma is misnamed and has an epithelial derivation.

Occasional capillaries are seen within the tumours but most blood-containing spaces which appear on light microscopy to be vascular channels are lined by cells with epithelial characteristics. The round cells interpreted as neoplastic cells by Katzenstein et al, ${ }^{10}$ which are characterised by uniform, blandappearing, round nuclei with abundant pale cytoplasm and situated within the stroma, also appear to have epithelial characteristics on ultrastructural examination.

Many of the cells, whether lining channels or papillae, forming sheets, or lying within sclerotic areas, had features of type 2 pneumocytesmicrovillous borders, specialised junctions, and complex lamellated bodies. Other cells retained the first two characteristics but had only what we interpreted to be rudimentary "osmiophilic bodies." We base this interpretation on the fact that similar dense bodies were present in the same cells as more complex lamellated inclusion bodies typical of type 2 pneumocytes and forms intermediate between the two. Moreover, the "rudimentary bodies" show features similar to those described in the developing human fetus. ${ }^{23} 24$ Furthermore, the additional presence of mucous cells supports an epithelial derivation.

Many published reports of sclerosing haemangioma have been of isolated cases. ${ }^{2-9} 11_{-18}$ Our series of 14 cases, occurring during 1974-80, seems unusually large. Whether this is fortuitous or due to some environmental factor in Hong Kong remains conjectural. The striking preponderance in women makes it tempting to compare this tumour to the liver cell adenoma occurring in women taking contraceptive pills. $^{26-28}$ Interestingly, many Chinese women ingest Chinese herbs for various conditions-for example, Angelica sinensis (Tangkuei) after menstruation. Perhaps studies of the effects of these herbs on animals would prove fruitful. That the tumour could represent an unusual pulmonary response to an insult during pregnancy is unlikely since occasional cases have been recorded in men ${ }^{10}$ and a very few in children. ${ }^{4}$

The true nature of this tumour is debatable. We do not believe that it represents an inflammatory process, since it is usually a discrete, circumscribed lesion; inflammatory cells are not always evident; and the pneumocytes composing the tumour appear immature ultrastructurally and histochemically. It is unlikely to be hamartomatous since it usually presents, and may be seen to expand, in adult life. We believe it to be a benign neoplasm; and the suggestion made by Hill and Eggleston, ${ }^{13}$ that it develops from primitive, incompletely differentiated cells derived from respiratory bronchioles, is the one we find most attractive. This would explain the variation in appearance of the epithelial cells. Furthermore several studies have demonstrated that alveolar epithelium differentiates from respiratory epithelium. ${ }^{23}{ }^{24}$ Perhaps some environmental factor or sex hormone plays a part in its pathogenesis.

As our observations show that the major cell type within these lesions manifests the characteristics of pneumocytes, we consider the name sclerosing haemangioma inappropriate and likely to perpetuate confusion. The conspicuous light-microscope features of haemorrhage and fibrosis are accompanied by a cellular proliferation of pneumocytes, and we consider that the most appropriate name for this lesion is "benign sclerosing pneumocytoma." We would emphasise the value of electronmicroscope examination, even of formalin-fixed material, wherever there is any difficulty in establishing this diagnosis.

We wish to thank Dr TB Teoh for permission to publish cases 1, 2, 3, and 4; Mr LH Ma for technical assistance; Mrs A Kwan, Mrs V Hamilton, and Miss J Stitfall for secretarial assistance; and Professor ED Williams for guidance in the preparation of this manuscript. 


\section{References}

'Liebow AA, Hubbell DS. Sclerosing hemangioma (Histiocytoma, xanthoma) of the lung. Cancer 1956;9:53-75.

${ }^{2}$ Rubin EH, Rubin M, Sicklick E. Circumscribed sclerosing hemangioma of the lung appearing as "coin" lesions. Cancer 1958;11:713-25.

${ }^{3}$ Arean VM, Wheat MW Jr. Sclerosing haemangiomas of the lung. A case report and review of the literature. Am Rev Respir Dis 1962;85:261-71.

${ }^{4}$ Mori S. Sclerosing haemangioma of the lung. Dis Chest $1968 ; 54: 381-4$.

${ }^{5}$ Long, FL, Nott DB, MacArthur EB. Xanthomatous tumour of the lung with identification of lipid content. Aust Ann Med 1970;19:362-5.

- Kaufman G, Goldberg M, Tyagi NS. Non-neoplastic sclerotic pulmonary lesion (sclerosing hemangioma). Report of a case. Am Rev Respir Dis 1971;104:742-6.

${ }^{7}$ Nair S, Nair K, Weisbrot IM. Fibrous histiocytoma of the lung (sclerosing haemangioma variant?). Chest 1974;65:465-8.

${ }^{8}$ Kahn LB, Dietrich BE. Sclerosing haemangioma of the lung. A case report. $S$ Afr Med J 1975;49:971-5.

9 Spencer H. Pathology of the lung. 3rd ed. Oxford: Pergamon Press, 1977:933-6.

${ }^{10}$ Katzenstein A-LA, Gmelich JT, Carrington CB. Sclerosing haemangioma of the lung. A clinicopathologic study of 51 cases. Am J Surg Pathol 1980;4:343-56.

" Hass JE, Yunis EJ, Totten RS. Ultrastructure of a sclerosing hemangioma of the lung. Cancer 1972;30:512-8.

${ }^{12}$ Kay S, Still WJS, Borochovitz D. Sclerosing hemangioma of the lung: an endothelial or epithelial neoplasm? Hum Pathol 1977;8:468-74.

${ }^{13}$ Hill GS, Eggleston JC. Electron microscopic study of so-called "pulmonary sclerosing hemangioma." Report of a case suggesting epithelial origin. Cancer 1972;30:1092-106.

${ }^{14}$ Kennedy A. "Sclerosing haemangioma" of the lung: an alterna- tive view of its development. J Clin Pathol 1973;26:792-9.

is Heilman E, Feiner H. The role of electron microscopy in the diagnosis of unusual peripheral lung tumours. Hum Pathol 1978;9:589-93

${ }^{16}$ Mikuz G, Szinicz G, Fischer H. Sclerosing angioma of the lung. Case report and electron microscope investigation. Virchows Arch A Pathol Anat Histol 1979;385:93-101.

${ }^{17}$ Palacios JJN, Escribano PM, Toledo J, Garzon A, Larru E, Palomera J. Sclerosing haemangioma of the lung. An ultrastructural study. Cancer 1979;44:949-55.

18 Alvarez-Fernandez A, Escalona-Zapata J. Sclerosing haemangioma of the lung. A histochemical, electron miscoscopical, tissue culture and time-lapse cinematograph study. Histopathology 1981;5:579-88.

19 Bancroft JD. Histochemical techniques. 2nd ed. London: Butterworths, 1975:246-7, 259-61.

${ }^{20}$ Gomori G. Microscopic histochemistry: principles and practice. Chicago: University of Chicago Press, 1952.

${ }^{21}$ Corrin B, Clark AE, Spencer H. Ultrastructural localisation of acid phosphatase in the rat lung. $J$ Anat 1969;104:65-70.

${ }^{22}$ Sorokin S. Histochemical events in developing human lungs. Acta Anat 1960;40:105-19.

${ }^{23}$ McDougall J, Smith JF. The development of the human type I pneumocyte. J Pathol 1975;115:245-51.

${ }^{24}$ Campiche MA, Gautier A, Hernandez EI, Reymond A. An electron microscope study of the fetal development of human lung. Pediatrics 1963;32:976-94.

${ }^{25}$ Braunstein H, Freiman DG, Gall EA. A histochemical study of the enzymatic activity of lymph nodes. I. The normal and hyperplastic lymph node. Cancer 1958;11:829-37.

${ }^{26}$ Baum JK, Holtz F, Bookstein JJ, Klein EW. Possible association between benign hepatomas and oral contraceptives. Lancet 1973;ii:926-9.

${ }^{27}$ Anonymous. Liver tumours and the pill. Br Med J 1977;ii:345-6.

${ }^{28}$ Klatskin G. Hepatic tumours: Possible relationship to use of oral contraceptives. Gastroenterology 1977;73:386-94. 